\title{
Correction to: The influence of standards and patents on long-term economic growth
}

\author{
Knut Blind ${ }^{1,2}$ D . Florian Ramel ${ }^{1} \cdot$ Charlotte Rochell $^{1}$
}

Published online: 9 August 2021

(c) The Author(s) 2021

\section{Correction to: The Journal of Technology Transfer https://doi.org/10.1007/s10961-021-09864-3}

The original version of this article unfortunately contained a mistake. There was a typo in the author name Charlotte Rochell. The original article has been corrected.

Publisher's Note Springer Nature remains neutral with regard to jurisdictional claims in published maps and institutional affiliations.

The original article can be found online at https://doi.org/10.1007/s10961-021-09864-3.

Knut Blind

knut.blind@tu-berlin.de

1 Chair of Innovation Economics, Technische Universität Berlin, Sekr. H47, Straße des 17. Juni 135, 10623 Berlin, Germany

2 Fraunhofer Institute of Systems and Innovation Research, Breslauer Strasse 48, 76139 Karlsruhe, Germany 